\title{
$\underline{\text { Cudworth as a Critic of Hobbes }}$
}

Stewart Duncan

Draft for Marcus Adams (ed.), A Companion to Hobbes

\begin{abstract}
$\underline{\text { Abstract }}$
This chapter considers Ralph Cudworth as a philosophical critic of Hobbes. Cudworth saw Hobbes as a representative of the three views he was attacking: atheism, determinism, and the denial that morality is eternal and immutable. Moreover, he did not just criticize Hobbes by assuming that a general critique of those views applied to Hobbes's particular case. Rather, he singled out Hobbes, often by quoting him, and argued against the distinctively Hobbesian positions he had identified. In this chapter I look at Cudworth as a critic of Hobbes in two of the three central areas, atheism and ethics, focusing on passages where we see him explicitly picking out Hobbes.
\end{abstract}

\section{$\underline{\text { Keywords }}$}

Hobbes; Cudworth; atheism; ethics; morality

\section{Introducing Cudworth}

Ralph Cudworth (1617-88) was the son of a fellow of Emmanuel College, Cambridge, where he himself studied and was later elected as a fellow. He became in 1645 Master of Clare College and Regius Professor of Hebrew, and in 1654 Master of Christ's College. As a philosopher, he has never quite become a canonical figure, but was also never quite forgotten, being mentioned in such places as Hegel's lectures on the history of philosophy and Ueberweg's Grundriss der Geschichte der Philosophie, as well as histories of British Moralists and Cambridge Platonists. 
Cudworth's major philosophical publication in his lifetime was The True Intellectual System of the Universe: The First Part; Wherein, All the Reason and Philosophy of Atheism is Confuted; And its Impossibility Demonstrated (henceforth, System). ${ }^{1}$ The one modern edition in English of a work of Cudworth's presents his Treatise Concerning Eternal and Immutable Morality (henceforth, Treatise) and his Treatise of Freewill (henceforth, Freewill). ${ }^{2}$ Neither of those was published in Cudworth's lifetime, but they correspond to parts of a plan of writing reported in the Preface to the System. There Cudworth says that he aimed to write three books: one "Against Atheism"; "For such a God as is not meer Arbitrary Will Omnipotent, Decreeing, Doing, and Necessitating all Actions, Evil as well as Good; but Essentially Moral, Good and Just"; and one "Against Necessity Intrinsecall and Essentiall to all Action; and for such a Liberty, or Sui-Potestas, in Rational Creatures, as may render them Accountable, capable of Rewards and Punishments, and so Objects of Distributive or Retributive Justice". ${ }^{3}$ The True Intellectual System is the first part of this, the Treatise corresponds roughly to the projected second book, and Freewill (and other manuscripts on that topic) to the third.

Reading Cudworth's philosophical works, one finds many references to other philosophers, often ancient philosophers. Consider for example the first chapter of the Treatise, which introduces the view that nothing is good or evil, just or unjust "naturally and immutably" (Cudworth 1996, 9). It does this by noting mentions of this view in Plato's works, then in Aristotle's; looking for evidence in Plato, Diogenes Laertius, and Plutarch of who the ancient proponents of this view were; and by observing the Epicurean history of the view. Only then does Cudworth come to a "late

\footnotetext{
${ }^{1}$ Other publications of Cudworth's include $A$ Discourse Concerning the True Notion of the Lord's Supper (1642), A Sermon Preached Before the Honourable House of Commons (1647), and A Sermon Preached to the Honourable Society of Lincons-Inne (1664).

2 The edition is Cudworth (1996). A short extract from the System appears in Clarke and Collins (2011), and there is a modern German translation of Cudworth's sermon preached before the House of Commons (Cudworth 2018). The Treatise was not published until the eighteenth century, and Freewill not until the nineteenth.

${ }^{3}$ System, "Preface to the Reader", third un-numbered page.
} 
writer of ethics and politics”, whom he quotes but does not name: Hobbes (Cudworth 1996, 13).

The survey does not end there however, but moves to theological versions of the view, mentioning

Ockham and others following him, before turning to "some [more recent] late authors", most of whom Cudworth does not name (Cudworth 1996, 15). ${ }^{4}$

In that chapter, as elsewhere in Cudworth's philosophical writings, there is a great deal of engagement with ancient philosophy. Indeed, some people have thought of Cudworth largely as a historian or philologist. Cudworth was, however, consistently engaged with the philosophical views of his contemporaries. ${ }^{5}$ As we read his work, we see him criticizing Descartes, Gassendi, and Spinoza. ${ }^{6}$ But the one contemporary philosopher he comes back to again and again, even more than Descartes, is Hobbes.

It would be an exaggeration to say that the System is just a giant argument against Hobbes. Many views that are distant from Hobbes's are considered there. But Cudworth did see Hobbes as a representative of exactly the three views he was attacking: atheism, determinism, and the denial that morality is eternal and immutable. Moreover, he did not just criticize Hobbes by assuming that a

\footnotetext{
${ }^{4}$ The one who is named is Joannes Szydlovius. Cudworth $(1996,15)$ refers to his "book published at Franeker”, Szydlovius (1643). On Szydlovius (or Szydłowski) see Cudworth (1996, 15 n.31); Kiedroń (2013, 223); Kronen (2015, 239); and Wojcik (1997, 193 n.9).

${ }^{5}$ Locke suggested that Cudworth's book could be used as a textbook of ancient Greek philosophy (Locke 1823, 9.185-186). More recently, Levitin $(2016,16)$ has described Cudworth "as a cuttingedge European philologist".

${ }^{6}$ In the System, there are about a dozen references to Descartes by name (System 39, 54, 161, 174-5, 646, 672, 684, 721, 724, 761, 843, 863, 882), Gassendi's views are noted and criticized (System 462, 641, 697, 769), and one passage criticizes Margaret Cavendish's views (System 137-8). Cudworth also cites chapters 19 (System 656) and 6 (System 707) of Spinoza's Tractatus Theologico-Politicus. This second reference, to the chapter on miracles, is noted by Colie $(1963,187)$ and Israel $(2006,446)$, who both also argue that Cudworth's criticism of hylozoic atheism was intended as criticism of Spinoza. Cudworth describes hylozoic atheism as a view "that attributes to all Matter, as such, a certain Living and Energetick. Nature, but devoid of all Animality, Sense and Consciousness" (System 135), and says in the Preface to the System that he has "certain Knowledge of [this view's] being of late Awakened and Revived" (ninth un-numbered page). Passmore $(1990,6)$ adds that "In one of his manuscripts Cudworth refers to Spinoza as 'a kind of hylozoic atheist”, referring to British Library MS 4982, p.55.
} 
general critique of those views applied to Hobbes's particular case. Rather, he singled out Hobbes, often by quoting him, and argued against the distinctively Hobbesian positions he had identified. ${ }^{7}$ In this chapter I look at Cudworth as a critic of Hobbes in two of the three central areas, atheism and ethics, focusing on passages where we see him explicitly picking out Hobbes. ${ }^{8}$

\section{Hobbes and atheism in the True Intellectual System}

Cudworth's System is a defense of theism against atheism. The arguments of that defense might all seem to be aimed at types of position, which are associated with ancient figures, if with any individuals at all. There is, for example, a general attack upon atomic (or Democritick or Epicurean) atheism. There are also attacks on other types of atheism, which Cudworth calls hylozoic, hylopathian, and cosmo-plastick atheism. We might reasonably take the attack on the Epicurean view to be aimed in part at Hobbes. ${ }^{9}$ But there is also a more specific attack on Hobbes, in passages that are clearly aimed at him in particular. In those passages, Cudworth quotes and criticizes a "modern writer", who is Hobbes. ${ }^{10}$ Those passages are the main focus of my discussion in this section.

\footnotetext{
${ }^{7}$ Mosheim's notes (Cudworth 1733; Cudworth 1820) are helpful in identifying what passages in Hobbes's work Cudworth is referring to.

${ }^{8}$ Space being limited, I do not here discuss Cudworth's criticisms of Hobbes on freewill. On Cudworth on freewill, see Leisinger (forthcoming) and Passmore (1990). On Cudworth's criticisms of Hobbes's determinism, see Irwin (2007, 247-9).

${ }^{9}$ See Duncan and LoLordo (forthcoming). Sarah Hutton says that Hobbes is a hylopathian atheist, not an atomic one (Hutton 1996; Hutton 2013). She argues that "Hobbes, by denying the existence of spirit altogether, but not denying the existence of God is a material atheist of the hylopathian variety" (Hutton 1996, 27). Cudworth, however, thought that Hobbes denied the existence of God. Beyond that, Cudworth's main contrast between hylopathian and atomic atheism seems to lie in the conception of matter, not in a different view about the existence of God. Thus he distinguishes "the Hylopathian or Anaximandrian, that derives all things from Dead and Stupid Matter in the way of Qualities and Forms, Generable and Corruptible" from "the Atomical or Democritical, which doth the same thing in the way of Atoms and Figures" (System 135).

${ }^{10}$ It depends a little on how one counts, but there something like seventeen such passages with identifiable direct references.
} 
The passages that quote Hobbes are in chapter 2, where Cudworth is presenting arguments for atheism, and in chapter 5, where he is responding to them. In those passages, six themes emerge: (1) the argument for atheism from our having no idea of God (which connects to Hobbes's deflationary account of apparent descriptions of God's attributes); (2) the explanatory role of fear in Hobbes's view; (3) arguments from principles of motion and causation; (4) the role of politicians; (5) knowledge, understanding, and nominalism; and (6) materialism about the mind. ${ }^{11}$ In this section I concentrate on the first of these themes, which is the one about which Cudworth has most to say. Looking at what he says about it shows us how he understands Hobbes's views, as well as how he wants to criticize them.

\subsection{An argument for atheism}

My starting point here comes from the beginning of Cudworth's exposition of arguments for atheism:

The grounds of Reason alledged for the Atheistical Hypothesis are chiefly these that follow. First, That we have no Idea of God, and therefore can have no Evidence of him; which Argument is further flourisht and descanted upon in this manner. That Notion or Conception of a Deity, that is commonly entertained, is nothing but a Bundle of Incomprehensibles, Unconceivables, and Impossibles; it being only a compilement of all Imaginable Attributes of Honour, Courtship, and Complement, which the Confounded Fear, and Astonishment of Mens minds, made them huddle up together, without any Sence or Philosophick Truth (System 63).

\footnotetext{
${ }^{11}$ For relevant texts in the System on the explanatory role of fear, see System 63-4, 68-9, 96-7, 650-1, 655-6, and 891-2; on the role of politicians, 96-7, 697-9, and 891-2; on principles of motion and causation, 76-7 and 667-9; on knowledge, understanding, and nominalism, 730-2 and 853-4; and on materialism about the mind, 760-2 and 840-1.
} 
Cudworth follows that with two passages from Hobbes: a paraphrase of a discussion of the attributes of God early in the Questions Concerning Liberty, Necessity, and Chance (EW V.6), and a quote from chapter 46 of Leviathan on the same topic (Hobbes 2012, 1086; 1651, 374). ${ }^{12}$

In the discussion of this first argument for atheism we find an allegedly Hobbesian argument for atheism from the claim that we have no idea of God; the connection of that argument to Hobbes's views about divine attributes; an explicit connection to Hobbes himself by quotation; and then, after the quotes, a mention of the role that Hobbes gives to fear in explaining religious belief.

The argument for atheism itself seems to have this structure:

1. We have no idea of God;

2. If we can have no idea of something, then it does not exist; so

3. God does not exist.

Note what the conclusion here says about Cudworth's understanding of Hobbes. First, Cudworth believes that Hobbes is an atheist, in the sense that he denies the existence of God. ${ }^{13}$ Secondly, by associating this conclusion with Hobbes, Cudworth commits himself to a suspicious reading of Hobbes, on what Hobbes does not mean what he says. ${ }^{14}$ Hobbes, after all, does not say that God does not exist—indeed he keeps saying that He does. ${ }^{15}$

In his initial presentation, Cudworth gives us no quotation to connect the first premise to Hobbes, but it clearly is a claim Hobbes makes. Consider, for example, Hobbes's Objections to

\footnotetext{
${ }^{12}$ Cudworth gestures towards there being other passages; we might add De Cive 15.14 and a passage in chapter 31 of Leviathan (Hobbes 2012, 566; 1651, 190).

${ }^{13}$ That is, Cudworth does not just use 'atheist' to describe heterodox views about the nature of God, or as a mere term of abuse.

${ }^{14}$ Note the related suspicious reading of Gassendi, "another Learned Well-willer to Atheism" (System 641).

${ }^{15}$ This is not the place to talk at length about the pros and cons of suspicious readings of philosophers. I note however that Hobbes said plenty of controversial things, even if we take him at face value. If we are to give a suspicious reading of Hobbes, we will need a fairly complex theory of what he was up to- what he certainly did not do, was hide a controversial view behind a conventional facade.
} 
Descartes's Meditations. In the Meditations, Descartes offers two arguments for the existence of God, both of which begin by focusing on the meditator's idea of God. Hobbes objects to those arguments by denying that we have an idea of God. ${ }^{16}$

Premise 2 is more puzzling. Cudworth himself seemingly grants the acceptability of the premise, but does Hobbes believe or assert it? ${ }^{17}$ Hobbes seems to grant the existence of things of which we have no idea, most obviously God. (Hobbes believes we have a way to think about God that does not involve having an idea of him—a way of thinking of God relationally, with no conception of his intrinsic features.) Cudworth, however, is inclined to take Hobbes as deriving nonexistence from inconceivability. Perhaps Cudworth thought that a version of the argument from inconceivability to non-existence was a good one, and thus an uncontroversial attribution. But it is a little tricky to pin this on Hobbes, and this makes a significant difference to how one understands Hobbes. With this premise at hand, Hobbes has an obvious argument for atheism. Without it, he has a point about the extreme limits of our ability to think about God.

\subsection{Cudworth's arguments that we do have an idea of God}

\footnotetext{
${ }^{16}$ A note on terminology: Cudworth talks of ideas, and Hobbes uses that language when talking with Descartes, but generally prefers other terms elsewhere, such as 'phantasm'. I use 'idea' throughout the discussion in this chapter.

${ }^{17}$ Cudworth grants the claim "That what is so Utterly Unconceivable, as that no man can frame any manner of Idea or Conception of it, is therefore either in it self, or at least to us, Nothing (System 638). Why should one think this? Here Cudworth tells us that there is "some Truth in that of Aristotle, that ... the Rational Soul or Mind, is in a manner All things; it being able to frame some Idea and Conception or other, of whatsoever is in the Nature of things, and hath either an Actual or Possible Existence, from the very Highest to the Lowest. Mind and Understanding is as it were a Diaphanous and Crystalline Globe, or a kind of Notional World, which hath some Reflex Image, and correspondent Ray, or Representation in it, to whatsoever is in the True and Real World of Being And upon this account may it be said, that whatsoever is in its own Nature Absolutely Unconceivable, is indeed a NonEntity" (System 638). Whatever else we say about this, we can agree that it does not give us a Hobbesian reason to endorse premise 2.
} 
In responding to this argument for atheism, Cudworth's focus is on the first premise. He replies to the view that there is no idea of God, and to various arguments for it. Indeed, all of chapter 4 of the True Intellectual System is devoted to arguing that we do indeed have an idea of God. That is a long and complex chapter, filling over 400 pages. Much of it is occupied by discussions of pagan polytheism, and the question of what, if any, ideas of divinities those pagans had. Before that however, we find discussion of what the idea of God is: "the true and genuine Idea of God in general, is this, A Perfect Conscious Understanding Being (or Mind) Existing of it selffrom Eternity, and the Cause of all other things" (System 195). ${ }^{18}$ Even before that, Cudworth gives us two arguments that we do have an idea of God. He argues first that people who speak different languages all think about God, so there must be some idea they share (System 192). His second argument is that atheists have an idea of God, which they rely on in denying the existence of God (System 194).

These arguments succeed, at least, in pointing out that we seem to have some way of thinking of God. Given certain assumptions, it might seem obvious to conclude from that that we have an idea of God. But Hobbes has another way of accounting for the phenomena. We can, he grants, think about God relationally, as the cause of the world. This does not involve having an idea of God or any grasp on God's intrinsic features, because an idea of God would be an (impossible) image of God. Cudworth thus seems off target in his criticism of Hobbes here, or at least to need to say more. Indeed, there is an ambiguity about what it is to have an idea of God. ${ }^{19}$ If it is just to have some way of thinking about God, Hobbes and Cudworth agree that we have it. If it is to have an image of God, they agree that we do not. If it is to have an idea of "A Perfect Conscious Understanding

\footnotetext{
${ }^{18}$ Although "none should be condemned for Absolute Atheists, merely because they hold Eternal Uncreated Matter, unless they also deny, an Eternal Unmade Mind, ruling over the Matter, and so make Sensless Matter the Sole Original of all things" (System 199).

${ }^{19}$ Similarly, Cudworth had begun this discussion by invoking "Modern Atheists" who "stick not to maintain, That the Word God hath no Signification" (System 192), which sounds vaguely Hobbesian, but it is not quite Hobbes.
} 
Being (or Mind) Existing of it self from Eternity, and the Cause of all other things", then Cudworth thinks we have it, and Hobbes disagrees. Indeed, if it is to have any positive conception of the attributes of God, then again, Cudworth thinks we have it, and Hobbes disagrees. ${ }^{20}$

\subsection{Cudworth's response to arguments that we have no idea of God}

Aside from responding to the view that there is no idea of God, Cudworth also responds to arguments for it. We see these responses in his reply to the first argument for atheism at the start of chapter 5 of the System. There he lists arguments for the claim that we have no idea of God.

First, That we have no Idea nor Thought of any thing not Subject to Corporeal Sense; nor the least Evidence of the Existence of any thing, but from the same. Secondly, That Theists themselves acknowledging God to be Incomprehensible, he may be from thence inferred to be a Non-Entity. Thirdly, That the Theists Idea of God including Infinity in it, is therefore absolutely Unconceivable and Impossible. Fourthly, That Theology is an Arbitrarious Compilement of Inconsistent and Contradictious Notions; And Lastly, That the Idea and Existence of God ows all its being, either to the Confounded Non-Sence of Astonish'd Minds; or else to the Fiction and Imposture of Politicians (System 634).

Note three arguments here. Argument 1 is based on the thought that all our ideas, thoughts, and evidence derive from our senses. Argument 2 is based on the observation that theists say God is incomprehensible. Argument 3 moves from observing the claim that God is infinite, through the view that the infinite is inconceivable, to the conclusion that we have no idea of (such an infinite) God. $^{21}$

\footnotetext{
${ }^{20}$ This is much the same as the situation in Hobbes's Objections to Descartes's Meditations: Hobbes and Descartes agree that we have some way to think about God, and that we have no image of God, but disagree about whether we have the idea of God that Descartes's meditator claims to have, and indeed about whether we have any positive conception of the attributes of God.

${ }^{21}$ A final thought involves giving alternative, deflationary explanations of our thoughts of God, explanations that may be psychological or political. This consideration works in a different way than the others - it is not really an argument that we have no idea of God_-and is not discussed below.
} 
Argument 1. Ideas come from sense. Cudworth associates this sub-argument directly with Hobbes (System 634-7). ${ }^{22}$ Our ideas, Hobbes says, come from sensation and are image-like. They are ideas or phantasms of the imagination. We see a set of connected views here: that ideas are images, that they come from sense, and that we possess sense and imagination but not a further faculty of intellect. From this Cudworth draws the conclusion that, for Hobbes, things of which we can have no images, no sense-derived ideas, cannot be conceived.

Cudworth's reply to this argument starts with the thought that there is a higher faculty than sense (or, indeed, than imagination). The allegedly Hobbesian view makes sense the judge of all existence, but according to Cudworth there is a higher faculty, reason, which is a judge of these things, and leads us to things that sense cannot reach. More basically, on Cudworth's view, there are ideas which are not phantasms or images, and do not have phantasms "belonging to" them (System 636). Cudworth indeed gives the idea of God as an example here, which might indeed have seemed to him to be the clearest example, but was of course a contested one.

Argument 2. Theists say God is incomprehensible. More than once in the Third Objections, Hobbes appeals to the Christian view that God is inconceivable in support of his view that we have no idea of God. ${ }^{23}$ That is, Hobbes does indeed appear to have given this argument that Cudworth discusses.

${ }^{22}$ Thus he quotes the final paragraph of chapter 3 of Leviathan: "Thus a Modern Atheistick Writer; Whatsoever we can conceive, hath been Perceived first by Sense, either at once or in parts; and a man can have no Thought representing any thing not Subject to Sense. From whence it follows, that whatsoever is not Sensible and Imaginable, is utterly unconceivable and to us Nothing" (System 634).

${ }^{23}$ Note a comment in Hobbes's fifth objection - "this is why we are forbidden to worship God in the form of an image; for otherwise we might think that we were conceiving of him who is incapable of being conceived" (AT 7.180, CSM 2.127) —and one in his eleventh—"Since it has not been demonstrated that we have the idea of God, and since the Christian religion obliges us to believe that God cannot be conceived of (which means, in my view, that we can have no idea of him), it follows that no demonstration has been given of the existence of God, let alone the creation" (AT 7.189, CSM 2.133). 
Cudworth responds to this argument at some length, but his key move is to deny that the incomprehensible is inconceivable. God is incomprehensible, which is to say that we cannot have a conception of God that is "fully Adequate and Commensurate to" God (System 638). But this is not to say that we cannot conceive of God at all, only that we cannot fully understand God. Indeed, Cudworth argues, this is not such an unusual situation. It is common for us to be unable to grasp the essences of things: "even Body it self [...] hath such puzzling Difficulties and Entanglements in the Speculation of it, that they can never be able to extricate themselves from" (System 639). But that does not show that we have no ideas of those things, or that we cannot think about them at all. The same goes for God, even though God "is more Incomprehensible to us than any thing else whatsoever" (System 639).

Argument 3. God is said to be infinite. In considering the third argument, we find an even clearer connection to Hobbes. For in replying to this argument—which involves the claim that God is inconceivable because infinite-Cudworth again quotes Hobbes. ${ }^{24}$

In discussing this argument, Cudworth grants to the atheist that there is no phantasm (or imagistic idea) of the infinite. But this is of course not what he thinks the main issue is, as he does not think all ideas are phantasms. Cudworth also grants that we cannot fully comprehend the infinite. Indeed he goes further and grants that there are some infinites of which we have no idea: "That as for those Infinities, of Number, of Corporeal Magnitude, and of Time or Successive Duration, we have not only no Phantasm, nor Full Intellectual Comprehension of them, but also no manner of Intelligible Idea, Notion or Conception" (System 643). His central reason is that in these cases there are no actual infinites, only potential ones. If we think we have an idea of actual infinite space, for example, we

\footnotetext{
${ }^{24}$ Cudworth quotes De Corpore 26.1 and chapter 3 of Leviathan (Hobbes 2012, 46; 1651, 11). We see this thought back in the Third Objections as well (AT 7.186, CSM 2.131).
} 
are merely confused. Cudworth takes it, however, that the case of God is different. ${ }^{25}$ We have some notion of God as an infinite being, though we do not fully understand the infinity of God. This connects, then, to the general question of how, and to what degree, we can think about or understand God. Cudworth grants we do not have a complete understanding, but does think that we have ideas that represent God's nature, above and beyond the merely relational conception Hobbes thinks we have.

Cudworth's criticism of Hobbes's view that we have no idea of God is closely connected to his criticism of Hobbes's theory of the language we apparently use to describe the attributes of God. These two issues also have a close connection in Hobbes's thought. Our inability to form an idea of God is our inability to form a positive, non-relational conception of him. If we had such a conception, it would involve conceiving some of God's attributes-e.g., if we had an idea of God as an omniscient being, it would involve a conception of God's omniscience. The absence of such an idea involves, indeed basically just is, the absence of a positive conception of God's attributes.

Such conceptions may be absent, but people clearly do use language that seems to describe God's attributes. What is such language doing, in the absence of those conceptions? Hobbes's response to that situation is to argue that such language has a purpose, but the purpose is not to describe God's attributes. Language can be used to praise and honor God, without describing him.

Cudworth was well aware of this theory of Hobbes's. ${ }^{26}$ He himself had a very different approach, and a significant part of his reply to Hobbes's view consists in stating his view that we do have an idea of God as a perfect being. On the one hand, this idea is simple. On the other, we can

\footnotetext{
${ }^{25}$ Cudworth thinks that God has infinite duration — though infinite duration "cannot possibly belong to any Successive Being" (System 645), it can belong to God.

${ }^{26}$ He quotes several relevant passages: two from chapter 46 of Leviathan, one quoted at System 650 (Hobbes 2012, 1078; 1651, 371) and later one (in Hobbes's text) quoted at System 63-4 (Hobbes 2012, 1086; 1651, 374); De Corpore 7.12, quoted at System 641; and the Questions concerning Liberty, Necessity, and Chance (EW 5.6), quoted at System 63.
} 
demonstrate that a perfect being has indeed the various divine attributes. Cudworth grants, again, that we lack full understanding in this realm. Moreover, he suggests that talking in terms of multiple divine attributes is itself a sign of our lack of understanding in this realm. God's attributes are, on this story, "but so many Partial and Inadequate Conceptions, of One and the Same, Simple Perfect Being, taken in as it were by piecemeal: by reason of the Imperfection of our Humane Understandings, which could not fully Conceive it all together at once" (System 652). But this is not to say that talk of God's attributes is insignificant, or not descriptive at all. It may involve limited and imperfect descriptions but they are indeed, contrary to Hobbes, descriptions.

\section{Morality in the Treatise on Eternal and Immutable Morality}

\subsection{The structure and topics of the Treatise}

In the scheme announced at the start of the System, Cudworth's second book is supposed to tell us that there is such a "God as is not meer Arbitrary Will Omnipotent, Decreeing, Doing, and Necessitating all Actions, Evil as well as Good; but Essentially Moral, Good and Just'. From that, one might expect a book focused on God. From the title of the Treatise on Eternal and Immutable Morality (which corresponds, if anything does, to that projected second book) one might expect it to be a book focused on morality. On reading the Treatise, what one finds is a book focused on epistemology and psychology, where there is a lot of material on, for instance, the distinction between sense and intellect.

Though much shorter than the System, the Treatise is divided into four books. The first, and probably best-known, focuses on the question whether morality can depend on decision alone, human or divine. That leads Cudworth to a discussion in the second book of the view that there are no immutable natures or essences, a view he connects to Protagoras, among others. At the end of that book, Cudworth concludes that there is "another principle in us superior to sense, which judges 
what is absolutely and not fantastically or relatively only true or false" (Treatise 48). Starting from there, the third book discusses the difference between sense and knowledge, sensitive and intellectual cogitation. The fourth book continues that discussion, finding that the mind can, by its active powers, know the intelligible, immutable natures of things. Moral good and evil, just and unjust must themselves, according to Cudworth, have such natures.

Where does Hobbes fit in that long epistemological discussion? Cudworth's arguments for intellect as a source of knowledge are anti-Hobbesian, but they do not usually pick him out or argue against him explicitly. One notable exception is an explicit argument against Hobbes's nominalism (Treatise 116ff.). Hobbes of course thinks there are such things as reason and knowledge, but he understands them very differently than Cudworth does. His account does not include the thing that Cudworth emphasizes, the active mind that can grasp intellectual natures. Hobbes does think there is universal thought, and science, but he thinks those can be enabled by adding the power of language to an underlying psychology of imagistic representation. Cudworth thinks that is not enough to get us genuine knowledge. Meanwhile, Hobbes believes that the epistemic activity Cudworth finds most important, the active mind cognizing immutable natures, simply does not exist, so does not need to be explained.

\subsection{Against the view that morality depends on decision}

Book 1 of Cudworth's Treatise contains a relatively short, and apparently free-standing, argument that morality cannot arise merely from decisions, either human or divine. In recent decades, this has perhaps been the most-discussed part of Cudworth's work.

The question that connects the start and end of the Treatise is whether morality depends on God's will or his intellect. Those who think it depends on his will (thus, on decision-making) are Cudworth's primary target in the first book, before he starts to build his case that morality in fact 
depends on God's intellect. Hobbes—despite Cudworth's general interest in arguing against him—is rather an incidental target of the early argument. Hobbes agrees with Cudworth's main targets that morality depends on decision, but thinks that human decisions, not divine ones, are what's important (on Cudworth's reading of Hobbes, and many others). ${ }^{27}$

The central passage in Cudworth's argument is the following.

Wherefore in the first place, it is a thing which we shall very easily demonstrate, that moral good and evil, just and unjust, honest and dishonest (if they be not mere names without any signification, or names for nothing else but willed and commanded, but have a reality in respect of the persons obliged to do and avoid them) cannot possibly be arbitrary things, made by will without nature; because it is universally true, that things are what they are, not by will but by nature. As for example, things are white by whiteness, and black by blackness, triangular by triangularity, and round by rotundity, like by likeness, and equal by equality, that is, by such certain natures of their own. Neither can Omnipotence itself (to speak with reverence) by mere will make a thing white or black without whiteness or blackness; that is, without such certain natures, whether we consider them as qualities in the objects without us according to the Peripatetical philosophy, or as certain dispositions of parts in respect of magnitude, figure, site, and motion, which beget those sensations or phantasms of white and black in us (Treatise 16). ${ }^{28}$

\footnotetext{
${ }^{27}$ Here as elsewhere, Cudworth includes Hobbes among his atheistic opponents, not those with (merely) the wrong theological views. Thus, as far as Cudworth's reading of Hobbes goes, I disagree with Irwin (2007, 250), who says "Hobbes accepts voluntarism by treating the laws of nature as the commands of God". That is not an implausible reading of Hobbes, but it is not Cudworth's reading of him.

${ }^{28}$ On the Platonic heritage of this argument of Cudworth's, see Irwin (2003; 2006). But see also his comments on Cudworth as defending certain Scholastic views about the will and morality against Hobbes's criticisms (Irwin 2007, 240).
} 
Some commentators have thought this argument fails, because it is merely tautological. ${ }^{29}$ Cudworth does rely on the claim that "things are white by whiteness, and black by blackness, triangular by triangularity, and round by rotundity, like by likeness, and equal by equality", which sounds like a list of tautologies. His talk about natures is relevant though. Something cannot be made white, he says, without also being given the nature of a white thing-even God cannot simply declare something to now be white. Taking the talk about natures in a mechanical way, even God would have to arrange the small parts of the object so as to make it white..$^{30}$ That new arrangement of the small parts then explains why the object is now white.

Thus, when Cudworth says "things are white by whiteness", 'white' and 'whiteness' name two different things. On the one hand there's a way the object is: in this case, white. On the other hand, there's the underlying nature-what Cudworth calls the 'whiteness' - that explains why the object is that way. Sticking with the mechanical explanation, the whiteness is, roughly, the arrangement of the small parts of the object. Saying that the whiteness makes the thing white is giving an abbreviated explanation, not stating a tautology.

More generally, Cudworth claims that things do not acquire features just by decision, even by divine decision, but by acquiring the nature of a thing with that feature. Applying this principle to the case of goodness, even God cannot make thing good just by deciding it shall be good, for even God has also to give it the underlying nature of a good thing, whatever that may be.

In thinking about this argument, several possible objections might come to mind.

First, note that Cudworth is assuming that the principle about natures that holds in the examples above, about whiteness and so on, also holds of goodness. Perhaps it does, but it is open

\footnotetext{
${ }^{29}$ Zagorin (1992, 131-2). Compare Passmore (1990, 41-2).

${ }^{30}$ Cudworth thinks the argument would work equally well, if one took the talk about natures in a "Peripatetical" way. The key thought is that the presence of a feature must have an underlying explanation (which does not merely state an efficient cause).
} 
to someone to respond that it does not—-that goodness works differently. This non-reductive sort of response seems not open to Hobbes, though.

Secondly, there is a question about what the underlying nature is, that makes something good. For Cudworth's purposes here, however, we do not need to know what the nature is, just to recognize that there must be one (and that it does not just consist in having been decided). ${ }^{31}$

Thirdly, one might argue in response to Cudworth that not all obligations arise from the natures of the things we are obliged to do. For instance, if I promise to do X, there may be nothing in X considered alone that makes it obligatory. It nevertheless is obligatory, but just because I promised to do it.

Cudworth responds to that sort of objection, granting that in some cases a command can make a thing obligatory, when before we were obliged neither to do it nor to refrain from it. However, he says, this cannot be the source of all obligations. A command to do X would not create an obligation to do the intrinsically morally neutral X unless one were already obliged to obey the command. Thus:

we shall find that even in positive commands themselves, mere will doth not make the thing commanded just or obligatory, or beget and create any obligation to obedience; but that it is natural justice or equity which gives to one the right or equity of commanding, and begets in another duty and obligation to obedience (Treatise 18).

Cudworth's view is that, although some obligations may arise from commands or decisions, not all obligations may do so. Any obligation that arises from a command or decision must ultimately depend on an obligation that doesn't so arise. In a simple case, the dependence will be easy to see. Suppose we are obliged to obey the monarch's command because of the nature of the monarch, and the monarch commands that we do X. We become, thus, obliged to do X. The obligation to do $\mathrm{X}$ is

\footnotetext{
${ }^{31}$ On Cudworth on the nature of goodness, see Irwin $(2007,254)$.
} 
not ultimately explained by the decision alone. The explanation requires, rather, that the monarch be such they you should obey their decisions. ${ }^{32}$ More complicated cases are possible, but still, Cudworth says, there must be that basic obligation, one not grounded in a mere command, for the whole scheme to work. ${ }^{33}$

Evaluating this argument as criticism of Hobbes is tricky, insofar as it requires us first to say something about how exactly Hobbes thinks obligation arises. The question of where to locate the origin of normativity in Hobbes's system is not my topic here. Cudworth does however point us towards the difficult questions in that area. There are ways of reading Hobbes that find there is one basic obligation in Hobbes's system, from which others derive. If there is one basic obligation in the system, what is it and where does it come from? If there is none-if there really are just decisions at the base, and nothing else-why is there any normativity in the system at all?

\section{Conclusion}

Cudworth engaged repeatedly with Hobbes's philosophical writings. Hobbes, whom Cudworth saw as an atheist determinist who denied the eternal and immutable nature of morality, was a representative of all that Cudworth thought was bad in philosophy. But he was not just a representative of a broader trend-Cudworth picked out particular Hobbesian texts by quotation, and engaged with them in some detail.

We can see some of the broader disagreements of Hobbes and Cudworth, by looking at what they say about whether we have an idea of God. Most simply, Cudworth says we do, while

\footnotetext{
${ }^{32}$ We might even say the obligation is grounded in the nature of $\mathrm{X}$, if having been commanded by the monarch counts as part of the nature of X. See Prior $(1949,21)$. More generally, there are questions about what is to be included in the natures of things here. (For instance, does the relevant nature here include some fact about the monarch's relation to you, which explains by you must obey this monarch and not another?)

${ }^{33}$ For a possible response to this objection from Hobbes's perspective, see Irwin $(2007,258)$.
} 
Hobbes says we do not. Looking a little further, we see two different views about what ideas are, with Hobbes thinking they are all images, and Cudworth denying that. Looking beyond that, we see two different pictures of knowledge and the mind: Hobbes's view that relies just on the imagination and language being opposed by Cudworth's view of the intellect as an active being, capable of grasping eternal natures.

Sticking more closely to the question about God, we see Cudworth as an early suspicious reader of Hobbes: not accepting him as giving an account of out very limited ability to conceive of God, but taking him to deny God's existence, and to argue for that on the basis of our having no idea of God.

Issues about eternal natures arises again when we think about morality. Hobbes may not be the main target of Cudworth's argument that morality is not a matter of decision, but he is a target. Cudworth's criticism here points for us to a recurring and difficult question about Hobbes, the question of how there can be any normativity in the Hobbesian system. ${ }^{34}$

${ }^{34}$ I thank Antonia LoLordo for her comments on a draft of this chapter. 


\section{$\underline{\text { References }}$}

Clarke, Samuel, and Anthony Collins. 2011. The Correspondence of Samuel Clarke and Anthony Collins, 1707-08. Edited by William Uzgalis. Peterborough, Ontario: Broadview.

Colie, Rosalie L. 1963. "Spinoza in England, 1665-1730”. Proceedings of the American Philosophical Society 107(3): 183-219.

Cudworth, Ralph. A Discourse Concerning the True Notion of the Lord's Supper.

-1647. A Sermon Preached Before the Honourable House of Commons.

-1664. A Sermon Preached to the Honourable Society of Lincons-Inne.

1678. The True Intellectual System of the Universe.

- 1733. Radulphi Cudworthi Systema Intellectuale Hujus Universi. Trans. J. Mosheim.

- 1820. The True Intellectual System of the Universe. London.

-1996. A Treatise Concerning Eternal and Immutable Morality. Edited by Sarah Hutton.

Cambridge: Cambridge University Press.

- 2018. Predigt vor dem Unterhaus und anderen Schriften. Edited by Alfons Fürst and Christian Hengstermann. Münster: Aschendorff Verlag.

Darwall, Stephen. 1995. The British Moralists and the Internal Ought. Cambridge: Cambridge University Press.

Duncan, Stewart, and Antonia LoLordo. Forthcoming. "Early Modern Accounts of Epicureanism”. In Jacob Klein and Nathan Powers (ed.), The Oxford Handbook of Hellenistic Philosophy (Oxford: Oxford University Press).

Hutton, Sarah. 1996. "Lord Herbert and the Cambridge Platonists”. In Stuart Brown (ed.), British Philosophy and the Age of Enlightenment (Routledge) 20-42. 
—. 2013. “The Cambridge Platonists". In Edward N. Zalta (ed.), The Stanford Encyclopedia of Philosophy (Winter 2013 Edition).

https://plato.stanford.edu/archives/win2013/entries/cambridge-platonists.

Irwin, Terence. 2003. 'Morality and Immutability: A Platonic Contribution to Meta-Ethics', in R. W. Sharples (ed.), Perspectives on Greek Philosophy (Aldershot: Ashgate, 2003) 19-37.

—. 2006. "Socrates and Euthyphro: The Argument and its Revival". In Lindsay Judson \& Vassilis Karasmanis (ed.), Remembering Socrates: Philosophical Essays (Oxford: Oxford University Press) 58-71.

- 2007. The Development of Ethics. Volume 2: From Suarez to Rousseau. Oxford: Oxford University Press.

Israel, Jonathan. 2006. Enlightenment Contested. Oxford: Oxford University Press. Jesseph, Douglas. 2016. "Hobbes on the Foundations of Natural Philosophy". In A.P. Martinich and Kinch Hoekstra (ed.), The Oxford Handbook of Hobbes (Oxford: Oxford University Press) 134-48.

Kiedron, Stefan. 2013. “Jan Makowski (1588-1644). Polish Theologian in Frisian Franeker”. Odrodzenie i Reformacja w Polsce, special issue. http://dx.doi.org/10.12775/OiRwP.SI.2013.10. Kronen, John. 2015. 'Suárez’s Influence on Protestant Scholasticism: The Cases of Hollaz and Turretín”. In Victor M. Salas and Robert L. Fastiggi (ed.), A Companion to Francisco Suárez (Leiden: Brill) 221-47.

Leisinger, Matthew A. Forthcoming. “Cudworth on Freewill”. Philosophers' Imprint. Levitin, Dmitri. 2016. Ancient Wisdom in the Age of the New Science: Histories of Philosophy in England, $c$. 1640-1700. Cambridge: Cambridge University Press.

Passmore, J.A. 1990. Ralph Cudworth. Bristol: Thoemmes Antiquarian Books. A reprint of the 1951 edition. 
Prior, A.N. 1949. Logic and the Basis of Ethics. Oxford: Clarendon.

Joannes Szydlovius. 1643. Vindiciae questionum aliquot difficilium et controversarum in Theologia. Franeker.

Wojcik, Jan. 1997. Robert Boyle and the Limits of Reason. Cambridge: Cambridge University Press.

Zagorin, Perez. 1992. "Cudworth and Hobbes on is and ought”. In Kroll, Ashcraft, and Zagorin (ed.), Philosophy, Science, and Religion in England, 1640-1700 (Cambridge: Cambridge University Press). 